\title{
ATIVIDADE CONSCIENTE DO SER HUMANO: \\ FUNDAMENTOS FILOSÓFICOS DA PSICOLOGIA HISTÓRICO-CULTURAL
}

CONSCIOUS ACTIVITY OF HUMAN BEING:

PHILOSOPHICAL FOUNDATIONS OF CULTURAL-HISTORICAL PSYCHOLOGY

ACTIVIDAD CONSCIENTE DEL SER HUMANO:

FUNDAMENTOS FILOSÓFICOS DE LA PSICOLOGÍA HISTÓRICO-CULTURAL

ANJOS, Ricardo Eleutério dos ${ }^{1}$

\section{RESUMO}

Este artigo versa sobre o conceito de atividade consciente do ser humano como um tema para discussão dos fundamentos filosóficos da psicologia histórico-cultural. Para tanto, apresenta três categorias de análise, quais sejam: a atividade consciente e as necessidades histórico-culturais; a atividade consciente e a mediação cultural e; a atividade consciente e a apropriação da experiência do gênero humano. O artigo conclui que a consciência é um atributo do psiquismo humano engendrado pela complexidade da atividade social.

Palavras-chave: Atividade consciente. Psiquismo humano. Psicologia histórico-cultural.

\section{ABSTRACT}

This article examines the concept of conscious activity of human being as a topic of discussion on the philosophical foundations of cultural-historical psychology. Thus, three categories of analysis are proposed: conscious activity and social-historical needs; conscious activity and cultural mediation; conscious activity and appropriation of mankind's experience. It is concluded that conscious is an attribute of human psychism engendered in social activity.

Keywords: Conscious activity. Human Psychism. Cultural-Historical Psychology.

\section{RESUMEN}

Este artículo versa sobre el concepto de actividad consciente del ser humano como un tema para discusión de los fundamentos filosóficos de la psicología histórico-cultural. Para ello, presenta tres categorías de análisis: la actividad consciente y las necesidades histórico-culturales; la actividad consciente y la mediación cultural; la actividad consciente y la apropiación de la experiencia del género humano. El artículo concluye que la conciencia es un atributo del psiquismo humano engendrado por la complejidad de la actividad social

Palabras clave: Actividad consciente. Psiquismo humano. Psicología histórico-cultural

\footnotetext{
1 Universidade Estadual Paulista - UNESP - São Paulo - Brasil
} 


\section{INTRODUÇÃO}

Este artigo apresenta o conceito de atividade consciente do ser humano como um princípio explicativo do desenvolvimento psíquico. Defende, portanto, que o objeto de estudo da psicologia histórico-cultural não é a atividade em si, mas o psiquismo em atividade, notadamente em seu atributo humano, a consciência. Para tanto, parte dos pressupostos do materialismo histórico-dialético para fundamentar tal discussão.

A psicologia histórico-cultural surgiu na União Soviética no início do século $X X$, embasada no materialismo histórico-dialético, por meio de seus precursores Vigotski, Luria e Leontiev. Ela concebe a atividade consciente dos seres humanos como parte inseparável da totalidade da prática social que, diferentemente das concepções idealistas e biologicistas em psicologia, postula que a consciência é um atributo do psiquismo humano, engendrado por sua atividade vital, o trabalho. De acordo com Vygotski (2012, p. 268), "[...] o próprio intelecto do homem não poderia se desenvolver fora das condições da atividade humana específica, em particular à margem do trabalho".

Isso não significa, de forma alguma, que a psicologia histórico-cultural desconsidere os antecedentes da atividade humana na evolução das espécies. $E$, na verdade, não poderia desconsiderar, pois o materialismo de Marx e Engels sempre situou o gênero humano no interior do campo mais amplo que é o da natureza. Como explica Markus:

\footnotetext{
O que é o homem? Marx começa a responder a essa antiga questão filosófica partindo da premissa de um naturalismo materialista: "o homem é uma parte da natureza", ou seja, ele é um ser sensorial, físico, natural, trazido à existência por processos da natureza causais e não conscientes. (MARKUS, 2015, p. 21).
}

Nos Manuscritos econômico-filosóficos, Marx (2015) faz a distinção entre o ser humano e os demais animais por meio da diversidade de suas atividades vitais. A atividade vital é aquela que assegura a vida de toda espécie animal e, no caso dos seres humanos, assegura também a existência do gênero humano, da cultura. Por meio de sua atividade vital, um membro de uma espécie pode reproduzir a si mesmo como ser singular e, consequentemente, reproduzir sua própria espécie. No caso dos seres humanos, sua atividade vital - o trabalho - garante não só a existência da espécie humana (sua base biológica), mas, também, a produção e reprodução do gênero humano (cultura), ou seja, o trabalho assegura a existência da sociedade.

O trabalho é a atividade vital onde, diferentemente da atividade adaptativa dos demais animais, o ser humano modifica a natureza a fim de suprir suas necessidades. Trata-se de uma atividade que não tem uma relação direta com a satisfação de necessidades, mas sim, uma relação mediada, a partir da produção e utilização de ferramentas de trabalho e da linguagem ou, como diz Vygotski (2013), dos instrumentos técnicos e dos instrumentos psicológicos, os signos. 
A transformação objetiva da natureza engendrou no ser humano uma transformação subjetiva, posto que, a cada necessidade suprida, surgem novas e mais complexas necessidades, exigindo do ser humano um psiquismo mais complexo. Nesse sentido, podemos afirmar que "[...] o trabalho formou o ser humano e também sua consciência". (RUBINSTEIN, 1972, p. 128). Essa mesma complexidade psíquica será exigida àqueles que se apropriarem da cultura produzida por gerações precedentes.

Os pressupostos supracitados são analisados por Duarte (2013) como o processo dialético entre apropriação e objetivação, que outra coisa não é, senão, o processo que constitui a dinâmica fundamental da formação do gênero humano e dos indivíduos. O ser humano transforma a natureza impondo-Ihe características humanas, ajusta a natureza aos seus objetivos e atribui aos objetos naturais significados e funções sociais (processo de objetivação), que serão apropriadas por outros seres humanos (processo de apropriação). A partir do momento em que o ser humano passa a apropriar-se não mais da natureza diretamente, mas da matéria transformada pelo próprio homem, o processo de objetivação pode ser caracterizado pela produção e reprodução da cultura da humanidade.

Destarte, as características da forma superior de atividade, ou seja, da atividade consciente, atividade própria dos seres humanos, devem ser explicadas cientificamente, ancoradas no materialismo histórico e dialético. A gênese da complexidade da atividade psíquica do ser humano deve ser explicada a partir do trabalho e da consequente produção e utilização dos instrumentos de trabalho e da linguagem. Essa forma de vida não existe no mundo dos demais animais e "[...] as raízes do surgimento da atividade do homem não devem ser procuradas nas peculiaridades da 'alma' nem no íntimo do organismo humano, mas nas condições sociais de vida historicamente formadas”. (LURIA, 1979, p. 75, itálicos no original).

A partir do que foi exposto até o momento, podemos destacar três principais características da atividade consciente do ser humano que a distingue da atividade adaptativa dos demais animais: A primeira é que a atividade consciente do ser humano não é determinada apenas por necessidades biológicas, mas, sobretudo, por necessidades superiores, formadas a partir da complexidade da atividade social. A segunda característica é que a atividade humana é mediada, ao contrário da atividade imediata dos demais animais. Por fim, a terceira, refere-se ao fato de que a maioria de nossas atividades não é produzida pela hereditariedade, tampouco somente por experiências individuais, mas sim, pela experiência de toda a humanidade, a partir do processo de apropriação das riquezas humanas objetivadas ao longo do percurso histórico, e isso só pode ocorrer por meio do processo de educação. Analisemos mais de perto essas características acima mencionadas: 


\section{A ATIVIDADE CONSCIENTE E AS NECESSIDADES HISTÓRICO-CULTURAIS}

A primeira característica da atividade consciente do ser humano parte do pressuposto de que ela não está obrigatoriamente vinculada às necessidades biológicas. Ao criar necessidades superiores, necessidades propriamente sociais, o ser humano rompe com a antiga relação entre necessidades biológicas e atividade, num ciclo que poderia ser representado da seguinte maneira: "necessidade atividade - necessidade". Ao criar novas necessidades, necessidades especificamente humanas, a relação se inverteu, podendo agora ser representada como: "atividade - necessidade - atividade" (LEONTIEV, 1978a, p. 150). Em outras palavras, todo ser vivo é um ser ativo porque sua atividade busca suprir as necessidades mais básicas para garantir sua sobrevivência e de sua espécie. No caso dos seres humanos, a relação supracitada se inverte porque a complexidade de sua atividade engendra necessidades outras, que não são biológicas, mas sim, sociais. Assim, no princípio do desenvolvimento, as necessidades eram condição para a atividade, porém, na complexificação da atividade humana, o processo se inverteu e as necessidades tornaram-se seu resultado e, consequentemente, suscitaram e suscitam novas atividades.

Segundo Marx e Engels (2001), o ser humano cria a história por meio de sua atividade vital, pois modifica a natureza a fim de suprir suas necessidades e, consequentemente, surgem novas necessidades. Tal processo constitui o que os autores chamaram de "o primeiro ato histórico". Duarte (2013) explica que "o primeiro ato histórico" deve ser observado de forma dialética, constituído por dois aspectos, quais sejam: a produção dos meios de satisfação das necessidades humanas e, ao mesmo tempo, a produção de novas necessidades.

No entanto, na sociedade de classes, o processo de formação de novas necessidades se dá de forma contraditória. Enquanto que alguns poucos indivíduos detém a propriedade da maior parte da riqueza humana, a maioria da humanidade não tem acesso aos meios materiais e ideativos necessários tanto à satisfação de necessidades básicas como à formação de necessidades superiores. A contradição reside no fato de que a riqueza que se concentra nas mãos de poucos é produzida pelo trabalho de muitos. Esse quadro caracteriza-se como alienação, pois o desenvolvimento das necessidades humanas contradiz o desenvolvimento da personalidade da grande maioria dos indivíduos. Daí decorre a necessidade de uma sociedade mais equânime, onde cada indivíduo tenha acesso aos bens materiais e ideativos com vistas ao seu desenvolvimento omnilateral.

A força motriz da atividade consciente do ser humano caracteriza-se pelas novas necessidades superiores, necessidades culturais, engendradas na complexidade da atividade social. Tais necessidades sociais modificam, inclusive, as necessidades naturais, como é o caso da necessidade de alimentação, por exemplo: a fome que é saciada a partir do ataque de um predador que abocanha sua presa com unhas e dentes é distinta da fome saciada por um alimento levado ao fogo e ingerido por meio de garfo e faca (MÁRKUS, 2015). 
As necessidades superiores ou intelectuais são, por exemplo, necessidades cognitivas, as quais incitam o indivíduo a se apropriar de conhecimentos artísticos, filosóficos e científicos. São necessidades de comunicação, necessidades de ser útil à sociedade etc. (LURIA, 1979). No entanto, tais necessidades não são frutos da hereditariedade biológica, elas são produzidas socialmente. Isso quer dizer que, para que o indivíduo tenha necessidades de tais objetivações do gênero humano, fazse necessário que ele seja inserido em atividades que reproduzam os aspectos essenciais dessas objetivações.

O ser humano, movido por necessidades superiores, produziu meios mais desenvolvidos para se relacionar com a realidade a fim de satisfazer suas necessidades mais complexas. Tal asserção nos remete à segunda característica da atividade consciente do ser humano, qual seja: ela é uma atividade mediada pela cultura e não imediata como é a dos demais animais.

\section{A ATIVIDADE CONSCIENTE E A MEDIAÇÃO CULTURAL}

Luria (1979, p. 72) afirma que a atividade humana não toma como orientação "[...] a impressão imediata da situação exterior e sim um conhecimento mais profundo das leis interiores dessa situação, razão por que há todo fundamento para afirmar-se que o comportamento humano, baseado no reconhecimento da necessidade, é livre".

A atividade vital humana, a produção e utilização dos instrumentos de trabalho e da linguagem, possibilitaram aos indivíduos não se limitarem às percepções imediatas, emergindo daí, a consciência, o uso de mediações para se chegar a determinados fins. O ser humano, portanto, antecipa mentalmente os objetivos de suas ações de maneira que, ao final do processo de trabalho, há um produto que já existia na mente do indivíduo.

Dessa forma, entendemos que não é a consciência que determina a atividade humana, mas a atividade determina a consciência. Porém, esse processo deve ser compreendido em sua dialeticidade, o que se pode afirmar que a consciência é resultado da atividade e, consequentemente, condição específica para a forma humana de atividade, o trabalho. A consciência, na perspectiva marxiana, é um atributo do psiquismo humano engendrado pela complexidade da atividade social, portanto, não significa uma entidade alheia ao indivíduo, pois ela não é outra coisa, senão, o ser consciente (MARX; ENGELS, 2001).

A atividade consciente é uma relação mediada entre sujeito e objeto. $O$ ser humano criou meios artificiais para superar suas formas imediatas de relação com a natureza. Esses meios artificiais podem ser instrumentos de trabalho (as ferramentas) ou instrumentos psíquicos (os signos, na expressão de Vigotski), o que lhe proporcionou o desenvolvimento de formas complexas de conduta, formas específicas de comportamento humano como a memória lógica, a atenção voluntária e o pensamento abstrato. Como resultado de tal complexidade, o ser humano começou a dominar tanto a natureza externa, quanto sua própria natureza (VYGOTSKI, 2013). 
A atividade vital humana, o trabalho, portanto, é "[...] uma atividade que não visa diretamente, mas somente através de mediações, à satisfação de necessidades". (MÁRKUS, 2015, p. 27, itálicos no original). De início, o ser humano foi criando meios para satisfação de suas necessidades cotidianas e, no processo de complexificação das novas necessidades criadas pela prática social, foi também produzindo meios mais sofisticados e desenvolvidos para conhecer, dominar e transformar a realidade externa e, consequentemente, a realidade interna, sua subjetividade.

As produções do gênero humano ou objetivações genéricas que visam atender às necessidades cotidianas e pragmáticas são denominadas "objetivações genéricas em si" (DUARTE, 2013), dentre as quais destacamos a linguagem falada, os usos e costumes de determinadas sociedades e os utensílios e instrumentos ali produzidos e utilizados. Esse nível é considerado um "em si" porque as pessoas se relacionam espontaneamente com essas objetivações na cotidianidade, delas se apropriando de maneira pragmática, em decorrência do convívio social. São objetivações das esferas cotidianas do gênero humano que não exigem reflexão sistematizada por parte daqueles que delas se apropriam. Um exemplo desse tipo de objetivação é a linguagem. Os adultos ensinam a linguagem falada às crianças no objetivo de se comunicarem como elas, porém, as crianças se apropriam de tais objetivações de forma espontânea, pois não Ihes são ensinadas, a princípio, as análises sintáticas da língua, as regras gramaticais etc.

O nível das "objetivações genéricas para si" é mais desenvolvido e não é imprescindível às finalidades pragmáticas da vida cotidiana. Pertencem a esse grupo a ciência, a arte e a filosofia. Diferentemente das objetivações do primeiro grupo, essas requerem a superação da espontaneidade e do imediatismo da cotidianidade. Se por meio dos objetos, da linguagem e dos costumes os seres humanos constituem o gênero humano em si, por meio da ciência, da arte e da filosofia constituem o gênero humano para si. Disso decorrem também os níveis da individualidade em si e da individualidade para si (DUARTE, 2013).

Assim como o gênero humano ascendeu das esferas das objetivações genéricas em si às esferas das objetivações genéricas para si, importa que o indivíduo supere, por incorporação, sua individualidade em si com vistas à formação da individualidade para si, concebida como a máxima possibilidade da formação do indivíduo. Vale destacar que a passagem do cotidiano ao não cotidiano na vida dos seres humanos, bem como o controle do para si sobre o em si é um processo dialético de superação por incorporação. Não há como considerar uma separação rígida entre o em si e o para si, pois ambas as esferas de objetivações genéricas não possuem uma existência isolada. O ser humano, ao superar sua cotidianidade, incorpora-a e avança às esferas não cotidianas, num processo de síntese dialética entre ambas as esferas.

O indivíduo para si dirige sua vida cotidiana, ele hierarquiza de maneira consciente as atividades da cotidianidade, tem a possibilidade de conduzir a vida cotidiana a partir da mediação da relação consciente que tem com as esferas de objetivações genéricas para si. Portanto, segundo Duarte (2013), o indivíduo para si é capaz de distanciar-se de sua individualidade em si, ele é capaz de não considerá-la como definitiva e natural e, sobretudo, ele é capaz de transformá-la. 
As objetivações genéricas são meios criados pelos seres humanos com o intuito de satisfazerem suas necessidades. São mediações pelas quais os seres humanos se relacionam com a realidade externa e interna e, no caso das objetivações genéricas para si, se relacionam com a realidade para além de sua manifestação aparente, superficial. Por isso essa segunda característica destaca a diferença entre a atividade mediada do ser humano e a atividade imediata dos demais animais. De acordo com Luria (1979, p. 72),

\footnotetext{
Sabe-se que o homem pode refletir as condições do meio de modo imediatamente mais profundo do que o animal. Ele pode abstrair a impressão imediata, penetrar nas conexões e dependências profundas das coisas, conhecer a dependência causal dos acontecimentos e, após interpretá-los, tomar como orientação não impressões exteriores, porém leis mais profundas. (Itálicos meus).
}

A citação acima nos remete ao pressuposto marxista de que a realidade existe fora e independentemente da consciência dos indivíduos e que cabe a estes, representarem a realidade, ou melhor, representarem idealmente, no cérebro, o movimento da realidade objetiva. Como podemos observar no excerto supracitado, Luria insiste na ideia de que o ser humano, diferentemente dos demais animais, pode chegar ao conhecimento da realidade de forma aprofundada, para além da aparência fenomênica, indo a sua essência. Porém, a essência do fenômeno ou a apreensão do objeto para além de sua aparência, não está acessível imediatamente ao sujeito do conhecimento. A essência do fenômeno não se manifesta imediatamente, daí a necessidade de uma atividade peculiar por meio da qual o fundamento oculto das coisas seja descoberto.

Para se conhecer a essência das coisas é também necessário que haja a destruição da pseudoconcreticidade, isto é, da visão incorreta ou incompleta da realidade que se atém às aparências, à superfície da realidade. Sua destruição é necessária para a produção do concreto no pensamento, ou seja, para a elaboração de um correto conhecimento da realidade (KOSIK, 2011). Fica claro, portanto, que não é qualquer tipo de mediação que promove um conhecimento mais profundo do objeto ou do fenômeno dado. Para conhecer a realidade para além de sua aparência, é necessária a mediação das objetivações genéricas para si, das objetivações das esferas não cotidianas do gênero humano, como a ciência, a arte e a filosofia.

Marx (1978, p. 116-123) em O método da economia política, ao analisar o método científico de conhecimento, afirma que o pensamento parte da representação caótica do todo para chegar às abstrações. Em seguida, faz o caminho inverso, ou seja, ascende das abstrações mais simples à complexidade do conjunto que foi representado, inicialmente, de forma caótica. O pensamento afastase momentaneamente do concreto (captado pelo pensamento, inicialmente, como um todo caótico) por meio das abstrações para, em última instância, voltar ao concreto, porém, agora, representando suas múltiplas determinações (concreto pensado), ou seja, o reflexo subjetivo da realidade, no cérebro humano, avança na direção de um progressivo aprofundamento da explicitação racional do movimento da realidade. 
Para Marx, o concreto só pode ser captado pelo pensamento científico como ponto de chegada e não de partida. Ou seja, só pode ser captado adequadamente como síntese: "O concreto é concreto porque é a síntese de muitas determinações, isto é, unidade do diverso". (MARX, 1978, p. 116). O concreto no pensamento é o conhecimento mais profundo dos fenômenos da realidade, já que seu conteúdo não é o imediatamente observável, mas sim a síntese de múltiplas determinações que só é possível a partir das abstrações.

A análise crítica da dinâmica do capital que Marx desenvolve em suas várias obras é um modelo do movimento do pensamento científico que atinge o concreto por meio das abstrações. Mas esse método de elevação do abstrato ao concreto não se aplica apenas à análise da reprodução social regida pela lógica do capital. Trata-se de um método necessário às ciências de maneira geral. O passo, no pensamento, do concreto em sua forma caótica ao concreto pensado, por meio das abstrações, constitui a lei universal do desenvolvimento dos conhecimentos humanos e ocupa um lugar especial na dialética materialista.

Para evitarmos uma interpretação idealista, é necessário compreendermos que o caminho das categorias mais simples, abstratas e unilaterais para a complexidade e concreticidade do todo "[...] é o caminho do pensamento e não o da realidade, pois nela as categorias simples só têm existência no interior de um todo já existente". (DUARTE, 2008, p. 59). Tal observação é importante porque previne, em primeiro lugar, contra as ilusões idealistas as quais identificam o percurso do pensamento com os percursos da realidade que deve ser conhecida. Em segundo lugar, previne contra o reducionismo epistemológico, pois evidencia que o conhecimento científico da realidade "[...] não pode ser alcançado sem a mediação do árduo processo de elaboração de abstrações e de reconstrução, no pensamento, das múltiplas relações das quais o todo é composto". (Idem, p. 59). Portanto, o pensamento e o conhecimento não prescindem a realidade objetiva, pelo contrário, o conhecimento é a reprodução, é o reflexo subjetivo ou a representação mental, no cérebro, do movimento do objeto do conhecimento. Assim, o sujeito do conhecimento extrai, da realidade objetiva, as categorias de análise, a fim de conhecer a realidade para além de sua aparência superficial.

Outro caminho para a superação da aparência do fenômeno é o da arte. Enquanto que na ciência e na filosofia se faz necessário um "[...] detóur para conhecer as coisas e a sua estrutura". (KOSIK, 2011, p. 27), um afastamento em relação à aparência do fenômeno no objetivo de analisar suas múltiplas determinações, a arte mostra a aparência do fenômeno de outra forma, numa fusão com a essência, revelando ao sujeito a realidade constituída por suas contradições intensificadas, com a acentuação de sua dramaticidade (DUARTE, 2016).

A arte trabalha com imagens da realidade, entendendo aqui o termo imagem num sentido amplo, uma representação mental, ou seja, não limitado ao sentido da visão. Outro ponto importante que deve ser ressaltado é que a relação do indivíduo receptor com essas imagens artísticas da realidade é imediata. Porém, não se trata de uma relação imediata como ocorre na vida cotidiana. $A$ imediatez da vida cotidiana se resume no pragmatismo e satisfação imediata de necessidades. Na arte, 
a relação imediata é uma prática suspensa, as necessidades imediatas ficam em segundo plano e prevalece à entrega ao mundo da arte (DUARTE, 2016).

O papel educativo da arte, portanto, é provocar um salto qualitativo do em si ao para si, um salto da experiência cotidiana à experiência não cotidiana, seja ele no artista ou no receptor da obra de arte. Deixando claro que tal papel também é especificidade da ciência e da filosofia, porém, como demonstrado, por caminhos distintos. O indivíduo, por meio da obra de arte, pode reviver tramas humanas vividas num tempo e espaço muito distantes como se fosse parte de sua própria história. Pode produzir no sujeito receptor emoções mais fortes do que experimenta na maior parte de sua vida cotidiana. A arte, portanto, liga o percurso da vida individual ao percurso histórico da humanidade (DUARTE, 2016).

O papel da arte é produzir nas pessoas um efeito que as distancie de sua cotidianidade, que possibilite o indivíduo experimentar algo que está além de suas experiências diárias. Vigotski (1999) enfatiza tal assunto ao fazer uma comparação entre duas histórias bíblicas: A primeira história é a do milagre da multiplicação dos pães e peixes. $O$ autor utiliza esse exemplo para argumentar que o papel da arte não deveria se limitar a contagiar os indivíduos receptores com os sentimentos do artista. Também a arte não deveria ser reduzida à produção daquilo que é comum na vida das pessoas. $O$ primeiro conto bíblico é uma expressão de algo quantitativo: mil pessoas que se alimentaram e se saciaram com pães e peixes, ou seja, se alimentaram com o mesmo alimento que cada uma delas comia em sua vida diária. O outro milagre bíblico lembrado pelo autor é o da transformação da água em vinho. A maravilha da arte deve ser comparada a este último milagre. A arte deve promover transformação, deve promover superação do sentimento comum e das experiências da vida cotidiana. "A arte está para a vida como o vinho para a uva [...] a arte recolhe da vida o seu material, mas produz acima desse material algo que ainda não está nas propriedades desse material". (VIGOTSKI, 1999, p. 307-308).

A arte, como objetivação genérica para si, promove transformação na conduta do indivíduo, promove um salto qualitativo dos conceitos cotidianos aos conceitos científicos, processo indispensável para a inteligibilidade do real e à superação do imediatismo pragmático tão evidente na vida cotidiana (DUARTE, 2016).

No campo da psicologia científica, notadamente a partir da psicologia histórico-cultural, os pressupostos marxistas aqui explicitados servem, dentre outros fatores, de aportes teóricos para conceituar seu objeto de estudo, o psiquismo que, outra coisa não é, senão, o reflexo subjetivo ou a representação mental - no cérebro - da realidade objetiva. Essa representação mental da realidade é formada por meio de um sistema funcional complexo, constituído de funções psíquicas afetivocognitivas, como a sensação, percepção, atenção, memória, pensamento, linguagem, imaginação, emoção e sentimento (MARTINS, 2013). A internalização dos signos, ou seja, do universo simbólico objetivado ao longo do percurso histórico e cultural, proporciona o salto qualitativo das formas elementares de comportamento, configuradas no sistema "estímulo-resposta", às formas complexas de comportamento socialmente instituídas, ou seja, a transformação das funções psíquicas elementares 
em funções psíquicas superiores, funções especificamente humanas como a memória lógica, a atenção voluntária, a percepção semântica, o pensamento abstrato etc.

A representação mental da realidade torna-se mais fidedigna devido ao desenvolvimento do pensamento por conceitos, a nova forma de pensamento que se desenvolve a partir da adolescência. Esta forma de pensamento só pode ser desenvolvida a partir da apropriação de conteúdos não cotidianos como a ciência, a arte e a filosofia e possibilita o indivíduo conhecer a realidade para além de sua aparência.

As produções dos seres humanos são objetivações de suas capacidades e somente a partir da apropriação de tais objetivações genéricas, o indivíduo pode alcançar a complexidade psíquica a que tenha chegado o gênero humano até aquele momento histórico. Duarte (2013) denomina tal processo de "humanização", ou seja, a conquista histórica da liberdade humana pelo indivíduo, a começar pela transformação da natureza por meio do trabalho até às escolhas conscientes mediadas pelas objetivações genéricas, de acordo com a realidade concreta de cada um.

A existência humana, como uma conquista histórica que vai além da simples existência biológica, não é uma dádiva da natureza, portanto, o indivíduo precisa aprender a ser um ser humano (LEONTIEV, 1978b). Essa asserção pode ser compreendida a partir da distinção que Duarte (2013) faz entre as categorias "espécie humana" e "gênero humano". Todo ser vivo faz parte de uma espécie, no caso dos seres humanos, a espécie Homo Sapiens. Nossa espécie é caracterizada pelos aspectos biológicos que diferenciam o ser humano dos demais animais e que são transmitidos a cada indivíduo humano por meio da herança genética. Por outro lado, gênero humano é uma categoria constituída pelas características culturais formadas na história social e não são transmitidas pela herança genética, mas sim, por meio da apropriação das objetivações genéricas. Esse processo de objetivação e apropriação na formação do indivíduo ocorre de forma dialética, pois o indivíduo se forma a partir de um duplo processo de relacionamento com o gênero humano, compreendendo a apropriação das características humanas objetivadas e a objetivação individual mediada pelo que foi apropriado.

Tudo o que é propriamente humano (gênero humano), provém da vida em sociedade, por meio da apropriação da cultura objetivada ao longo da história. Porém, na sociedade de classes antagônicas, mesmo para o pequeno número que usufrui as aquisições da humanidade, "[...] estas mesmas aquisições manifestam-se na sua limitação, determinadas pela estreiteza e caráter obrigatoriamente restrito da sua própria atividade; para a esmagadora maioria das pessoas, a apropriação dessas aquisições só é possível dentro de limites miseráveis". (LEONTIEV, 1978b, p. 283).

Além da categoria "humanização", devemos considerar, portanto, seu oposto, a "alienação" (DUARTE, 2013), pois, numa sociedade dividida em classes sociais como é a capitalista, somente uma pequena parte dos seres humanos tem acesso às riquezas materiais e ideativas em suas formas mais complexas, enquanto a grande maioria dos indivíduos vive aquém do que já alcançou o gênero humano. Alienação ocorre quando os indivíduos são impedidos de se apropriarem das objetivações para si, ou seja, das esferas de objetivações não cotidianas do gênero humano, as quais possibilitam a universalidade e liberdade humanas. Destarte, o conceito de alienação deve ser entendido não de 
forma estanque e linear, mas a partir de distintos graus, de acordo com o maior ou menor acesso às objetivações humanas. Sendo a alienação um fenômeno social - decorrente da divisão da sociedade em classes e da apropriação privada da riqueza humana - uma de suas consequências para a formação humana é a da limitação da apropriação da cultura à reprodução da divisão social do trabalho.

Nessas circunstâncias o indivíduo não é formado como representante do gênero humano, mas sim, apenas como integrante de uma classe social. No interior das relações sociais de dominação o processo de desenvolvimento da personalidade se mostra de maneira contraditória, pois, ao mesmo tempo em que as objetivações genéricas oferecem condições para a humanização, isso não garante que o indivíduo se aproprie delas. O processo que possibilita a humanização é o mesmo que possibilita a alienação, colocando o indivíduo numa posição aquém daquela alcançada pelo gênero humano.

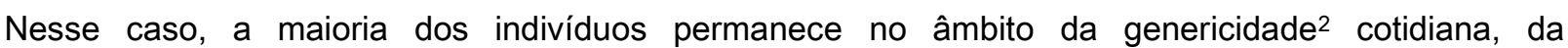
genericidade em si.

O fato de o indivíduo pertencer à espécie humana não lhe garante as características do gênero humano, isso porque a objetividade do ser humano é externa ao organismo, diferentemente dos demais animais cuja objetividade de sua espécie é herdada geneticamente. O gênero humano é externo ao corpo do indivíduo, o gênero humano é o "corpo inorgânico" do ser humano e isso quer dizer que seu desenvolvimento (desenvolvimento do gênero humano) não está limitado aos aspectos do corpo orgânico, aos aspectos biológicos, o que é uma vantagem em relação aos demais animais. Porém, no cerceamento da apropriação das objetivações genéricas, o ser humano regride a uma situação aquém do mundo animal, pois sua "[...] vantagem com relação ao animal [...]" é transformada em "[...] desvantagem de Ihe ser tirado o seu corpo inorgânico [...]". (MARX, 2015, p. 85).

Portanto, as produções materiais e ideativas do gênero humano não são dadas biologicamente, estão apenas postas. O ser humano deve se apropriar de tais produções humanas por meio de outros seres humanos, "[...] Pela sua função, este processo é, portanto, um processo de educação". (LEONTIEV, 1978b, p. 272). Essa citação nos remete à terceira característica da atividade consciente do ser humano que é analisada a seguir.

\section{A ATIVIDADE CONSCIENTE E A APROPRIAÇÃO DA EXPERIÊNCIA DO GÊNERO HUMANO}

De acordo com Luria (1979, p. 73), "[...] a grande maioria dos conhecimentos e habilidades do homem se forma por meio da assimilação da experiência de toda a humanidade, acumulada no processo da história social e transmissível no processo de aprendizagem". Nos demais animais, o comportamento é caracterizado apenas por duas fontes, quais sejam: a hereditariedade e os resultados da experiência individual. No caso do ser humano "[...] surge uma terceira fonte formadora da atividade: a transmissão e assimilação da experiência de toda a humanidade." (Idem, p. 75).

\footnotetext{
${ }^{2}$ Por genericidade entende-se a qualidade de pertencimento ao gênero humano.
} 
A atividade consciente não é inata e inerente ao ser humano, pois se trata de um processo de apropriação e objetivação das riquezas humanas, por meio do processo de educação. Por mais rica que seja a experiência individual do ser humano, não seria possível a formação de um pensamento abstrato, de uma memória lógica ou do domínio da atenção. De acordo com Leontiev (1978b, p. 266), "[...] seria preciso não uma vida, mas mil. De fato, o mesmo pensamento e o saber de uma geração formam-se a partir da apropriação dos resultados da atividade cognitiva das gerações precedentes".

Esse processo de aquisição da experiência da humanidade deve ser um processo ativo do ponto de vista do indivíduo, ou seja, ele exige do ser humano uma atividade adequada em relação às objetivações genéricas. Portanto, para se apropriar dos produtos do desenvolvimento histórico, "[...] é necessário desenvolver em relação a eles uma atividade que reproduza, pela sua forma, os traços essenciais da atividade encarnada, acumulada no objeto." (LEONTIEV, 1978b, p. 268). Essa atividade encarnada no objeto a que se refere Leontiev, não necessariamente diz respeito à atividade de produção desse objeto, mas também de sua utilização. Uma utilização adequada do objeto seja ele material, como a utilização de uma ferramenta, seja ele ideativo, como a utilização da linguagem, por exemplo.

A apropriação, de maneira adequada, do objeto material ou ideativo produzido por gerações precedentes provoca a formação de novos órgãos funcionais. Esses órgãos funcionais ou "neoformações" (LEONTIEV, 1978b) não significa a maturação de novos órgãos morfológicos do cérebro, mas sim, novos sistemas funcionais, resultado da complexidade da atividade humana que, ao mesmo tempo, configuram-se como condição para novas atividades.

Assim, devido à apropriação da cultura, o córtex cerebral humano se tornou capaz de formar novos órgãos funcionais. Podemos, então, afirmar que "[...] a cultura origina formas especiais de conduta, modifica a atividade das funções psíquicas, edifica níveis no sistema do comportamento humano em desenvolvimento." (VYGOTSKY; LURIA, 1996, p. 34). Essas neoformações se formam em decorrência da atividade humana e tais estruturas podem não se formar se certas atividades não existirem para uma determinada pessoa.

O adequado emprego do instrumento em determinadas atividades, a apropriação dos produtos materiais e não materiais produzidos por gerações anteriores, bem como a formação de novas funções psíquicas oriundas da relação dialética entre objetivação e apropriação, não podem se formar a partir do contato direto, imediato e espontâneo com os objetos da cultura. Tal processo só ocorrerá de forma efetiva a partir da transmissão precedente, a partir do processo de educação.

\section{CONSIDERAÇÕES FINAIS}

As atividades psíquicas dos animais formam-se nas condições de vida de cada espécie. As formas de vida que diferenciam a atividade consciente do ser humano da atividade adaptativa dos demais animais, que foram aqui apresentadas, são as formas histórico-culturais de atividade, ou seja, o trabalho e a produção dos instrumentos de trabalho e da linguagem. No processo de desenvolvimento 
histórico, o ser humano modifica os modos de sua conduta, ele cria novas formas de comportamento especificamente culturais. Desse modo, destacamos a importância de se estudar o conceito de atividade a fim de compreendermos a formação e o desenvolvimento do psiquismo humano.

Porém, ao elegermos o conceito de atividade consciente como tema de discussão dos fundamentos filosóficos da psicologia histórico-cultural, não podemos perder de vista que essa abordagem psicológica não tem como objeto de estudo a atividade em si. Corroboramos as palavras de Rubinstein (1976, p. 112) quando afirma que a "[...] atividade não é tema da psicologia [...]", o tema da psicologia é o psiquismo. A questão está em como estudá-lo: a) a partir de uma manifestação metafísica e apriori, b) a partir de uma manifestação biologizante e maturacional/evolucionista ou; c) dentro da atividade em que se forma e se manifesta. A psicologia histórico-cultural segue esse terceiro caminho.

\section{REFERÊNCIAS}

1. DUARTE, N. A anatomia do homem é a chave da anatomia do macaco: a dialética em Vigotski e em Marx e a questão do saber objetivo na educação escolar. In: Sociedade do conhecimento ou sociedade das ilusões?: quatro ensaios crítico-dialéticos em filosofia da educação. Campinas, SP: Autores Associados, 2008. p. 39-83.

2. DUARTE, N. A individualidade para-si: contribuição a uma teoria histórico-social da formação do indivíduo. 3. ed. rev. Campinas, SP: Autores Associados, 2013.

3. DUARTE, N. Os conteúdos escolares e a ressurreição dos mortos: contribuição à teoria históricocrítica do currículo. Campinas, SP: Autores Associados, 2016.

4. KOSIK, K. Dialética do concreto. 2. ed. Rio de Janeiro: Paz e Terra, 2011.

5. LEONTIEV, A. N. Actividad, conciencia y personalidad. Buenos Aires: Ciencias del Hombre, 1978a.

6. LEONTIEV, A. N. O desenvolvimento do psiquismo. Lisboa: Livros Horizonte, 1978b.

7. LURIA, A. R. Curso de psicologia geral: introdução evolucionista à psicologia. v. 1. Rio de Janeiro: Civilização Brasileira, 1979.

8. MÁRKUS, G. Marxismo e antropologia: o conceito de "essência humana" na filosofia de Marx. São Paulo: Expressão Popular, 2015. 
9. MARTINS, L. M. O desenvolvimento do psiquismo e a educação escolar: contribuições à luz da psicologia histórico-cultural e da pedagogia histórico-crítica. Campinas, SP: Autores Associados, 2013.

10. MARX, K. Manuscritos econômico-filosóficos e outros textos escolhidos. São Paulo: Abril Cultural, 1978. (Coleção Os pensadores).

11. MARX, K. Manuscritos econômico-filosóficos. São Paulo: Boitempo, 2015.

12. MARX, K.; ENGELS, F. A ideologia alemã. São Paulo: Martins Fontes: 2001.

13. RUBINSTEIN, S. L. Princípios de psicologia geral. Lisboa: Editorial Estampa, 1972.

14. RUBINSTEIN, S. L. Problemas de psicología general. México: Grijalbo, 1976.

15. VIGOTSKI, L.S. Psicologia da arte. São Paulo: Martins Fontes, 1999.

16. VYGOTSKI, L. S. Obras escogidas. Tomo I. Madrid: Visor, 2013.

17. . Obras escogidas. Tomo II. Madri: A. Machado Libros, S. A., 2001.

18 Obras escogidas. Tomo V. Madrid: Visor, 2012.

19. VYGOTSKY, L. S.; LURIA, A. R. Estudos sobre a história do comportamento: símios, homem primitivo e criança. Porto Alegre: Artes Médicas, 1996.

\section{Ricardo Eleutério dos Anjos}

Psicólogo e doutor em Educação Escolar pela UNESP/Araraquara. Pesquisador no Grupo de Pesquisa cadastrado no CNPq com o título: Estudos Marxistas em Educação, ligado ao Departamento de Psicologia da Educação da UNESP/Araraquara e no Grupo de Pesquisa GEDHEE - Grupo de Estudos em Desenvolvimento Humano e Educação Escolar - Pedagogia Histórico-crítica e Psicologia Históricocultural, da Universidade Estadual Paulista Júlio de Mesquita Filho, UNESP/Presidente Prudente. Atualmente é professor e supervisor de estágio em Psicologia Escolar/Educacional e Psicologia do Esporte (curso de psicologia da UNOESTE/Presidente Prudente) e professor de Psicologia da Educação (curso de Pedagogia da FATEB - $1^{\circ}$ lugar no Concurso Público da Fundação Municipal de Ensino de Birigui. Edital no 02/2013). 


\section{Como citar este documento:}

ANJOS, Ricardo Eleutério dos. Atividade consciente do ser humano: fundamentos filosóficos da psicologia histórico-cultural. Reflexão e Ação, Santa Cruz do Sul, v. 27, n. 1, dez. 2018. ISSN 19829949. Disponível em: <https://online.unisc.br/seer/index.php/reflex/article/view/11988>. Acesso em: 21 dez. 2018. doi:https://doi.org/10.17058/rea.v27i1.11988. 